\title{
An Examination of Socioeconomic Determinants of Average Body Mass Indices in Rwanda
}

\author{
Edward Mutandwa* \\ College of Forest Resources, Mississippi State University, P.O Box 9681, Mississippi, MS 39762, USA
}

\begin{abstract}
Obesity is increasingly becoming a common problem in Africa. Many studies have been pre-occupied with analyzing the causes of malnutrition whose effects are more pronounced. The main objective of this research was to determine the socio-economic factors that influence body mass indices in Rwanda. Inflation rate, body mass indices (bmi) for males and females (from 1960 to 2009) and food supply indices were obtained mainly from the Food and Agriculture Organization (FAOSTAT). A double log multiple regression model was used to assess the relationship between average bmi and several predictor variables. Further tests of autocorrelation, multicollinearity, heteroscedasticity and normality were carried out and subsequently corrected. Results showed that obesity is not a problem in Rwanda. However, bmi for men and women have been increasing. Food self sufficiency, fat supply and food aid had a positive and significant impact on average bmi $(\mathrm{p}<0.05)$ while GDP per capita and inflation rate were insignificant. These results indicate the positive impact of efforts of government of Rwanda through Vision 2020. However, food aid may be contributing to rapid bmi increases in the country.
\end{abstract}

Keywords: Gauss-Markov, multiple regressions, obesity, rwanda, socio-economic, vision 2020.

\section{BACKGROUND AND RESEARCH PROBLEM}

In the last three decades, obesity has been increasing at unprecedented rates globally [1,2]. Estimates indicate that approximately 1 billion people were either overweight or obese [3]. Assuming current socio-economic trends, it is estimated that there will be 1.35 billion obese people around the world in 2030 [4]. Although overweight (bmi $\geq 25$ ) and obesity (bmi $\geq 30$ ) have a global scope, there are large variations in terms of intensity among continents as well as countries [3]. The social, health and economic effects are being felt in developed countries mainly in the US, UK and Germany [3]. In the U.S, it is estimated that about $34 \%$ of the adult population are overweight compared with $15 \%$ in 1980 [5]. This has culminated in a burgeoning public health care expenditures of about $\$ 147$ billion per year in direct medical costs in the U.S. There are also significant economic costs in the form of lost work days due to health linked abseetnism [6]. Furthermore, obese individuals tend to spend about $\$ 1500$ more in health care expenditures when compared to normal adults [6].

Due to the severity of obesity in developed countries, literature on the subject has increased exponentially since the 1980s. Although bmi data is available for most less developed countries, relatively fewer studies have been carried out to explore the health implications of obesity and the root causes [7]. Traditionally, Africa has been known as the land of hunger but surprisingly about $25 \%$ of the adult

*Address correspondence to this author at the College of Forest Resources, Mississippi State University, P.O Box 9681, Mississippi, MS 39762, USA; Tel: +16626170038; E-mail: em851@msstate.edu population had a bmi $\geq 25$ in 2008 compared with $62.1 \%$ in the Americas and $57.4 \%$ in Europe [3]. Approximately 20$50 \%$ of urban people in Africa were obese in 2009 [8]. Literature on developing countries has been increasing since the turn of the millennium but a dearth of country specific analyses exists [7]. In South East Asia, about $14 \%$ of adults were overweight with China facing the highest likelihood of greater obesity challenges [3]. These statistics are not surprising since they seem to be correlated to the level of economic development. However, the irony particularly in Africa is the co-existence of over and under nutrition in different countries and families [9]. Countries faced with growing obesity problems in Africa include South Africa, Malawi, Namibia, Swaziland, Cameroon, Seychelles and Lesotho [3]. In addition, obesity is common in North African countries such as Morocco and Tunisia. Studies done in Tunisia and Morocco indicated that women were more obese than men with a prevalence rate of $51 \%$ and $17.8 \%$ respectively [10]. Furthermore, obesity is exacerbated by a general misconception that being "fat" implies being rich or well off. In South Africa, a greater proportion of women (56.6\%) were obese than men (29.2\%) [11]. Over nutrition was the main cause of being overweight.

This study focuses on Rwanda, an emerging agrarian based country, located in East Africa with an estimated population of 12 million on a surface area of approximately $27,000 \mathrm{~km}^{2}$ [12]. It has the highest population density in Africa of around 500 people per $\mathrm{km}^{2}$ [13]. The country has gone through debilitating political and social upheavals which culminated in a genocide that killed 1 million people in 100 days in 1994 [14]. Despite these historical setbacks, the government of Rwanda developed the Vision 2020 


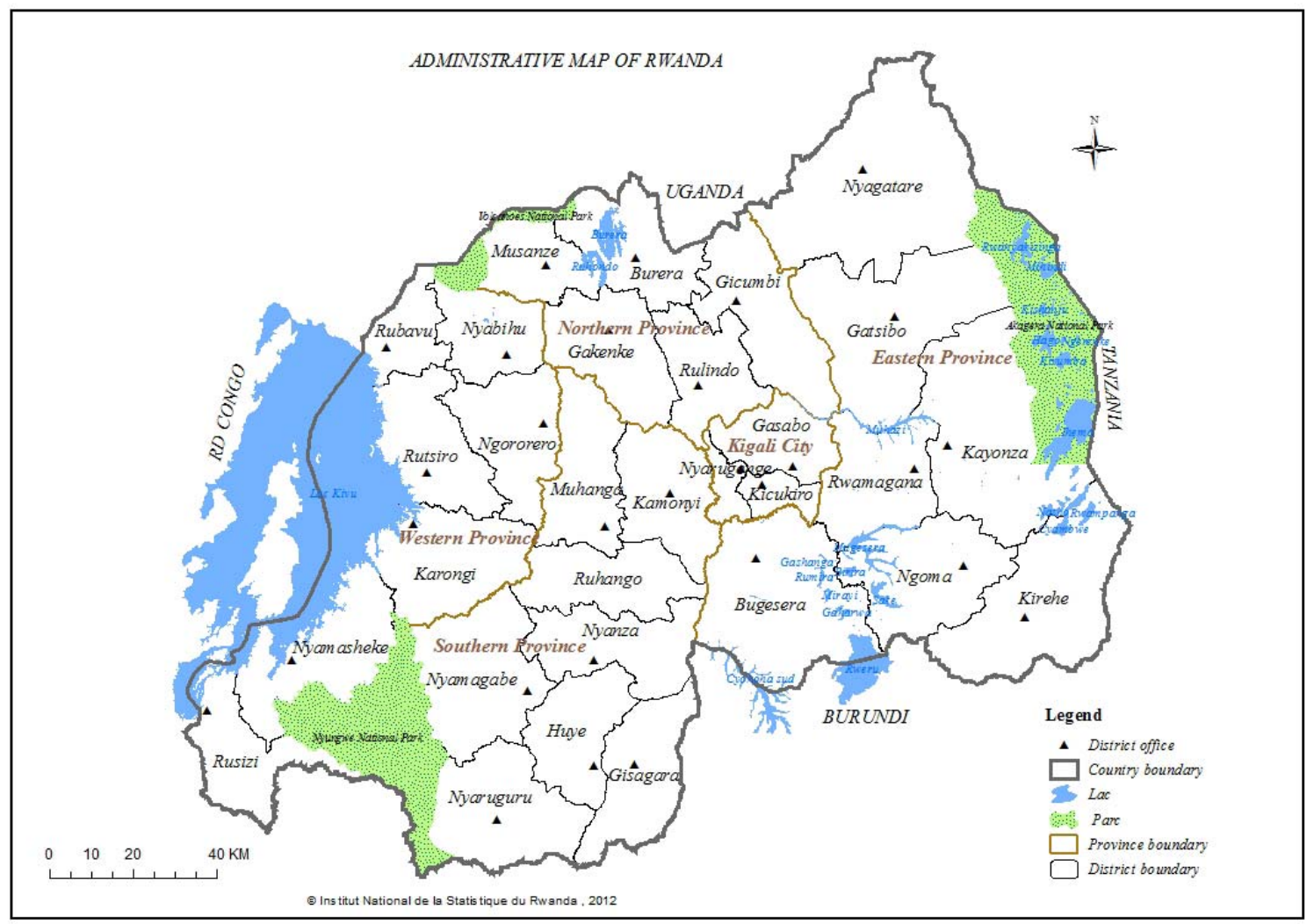

Fig. (1). Administrative map of Rwanda.

Source: NISR (2012)

policy strategy, whose main aim is to transform the country to a middle income state with a GPD per capita of US\$900 [15]. The use of subsidies in agriculture by the government (for example in the Crop Intensification Program and Land Use Consolidation) has led to improved agricultural productivity, increased food supply, and lower food prices [16]. These developments seem to have ushered a new socioeconomic and health challenge in the form of increasing bmi [3]. A recent study by the World Health Organization in 2012 indicated that $12.5 \%$ of women who had given birth were overweight while $1.3 \%$ were obese. The prevalence of obesity in Rwanda is linked to increasing income among urban people, high consumption of beverages, low physical activity levels, genetic factors and low educational opportunities [17]. The author further observes that lifestyle, cultural shocks and urbanization could be among the environmental factors influencing obesity in Rwanda. The government developed a national nutrition policy which is a part of a broader health sector strategy [14]. In addition, the government crafted a universal health care system covering about $92 \%$ of the population to have "affordable" health care services. The government acknowledges that efforts to reduce lifestyle related diseases such as obesity are nonexistent (p16). There is certainly a dearth of formal published studies examining the possible causes of increasing bmi in Rwanda. This paper ascertains the factors that influence the average bmi in Rwanda. The specific objectives are to: (1) present graphically and summarize data related to bmi, food supply (calories), fat and protein supply and food production indices over time (2) analyze the relationship between caloric intake and variables such as food prices and GDP per capita (3) assess current government interventions in the areas of healthcare and policy.

\section{RESEARCH METHODOLOGY}

\subsection{Description of Study Site}

Rwanda is divided into five Provinces namely Northern, Southern, Eastern, Western and Kigali City [14]. Disaggregated obesity statistics are difficult to obtain. However, obesity is likely to be prevalent in cities where formally employed people live. Fig. (1) depicts the different geographical zones in the country.

\subsection{Data Collection Methods}

This study mainly relied on secondary data obtained from three main sources namely the Food and Agricultural Organization Statistical Division (FAOSTAT), National Institute of Statistics of Rwanda (particularly national health and demographic surveys) and World Bank databases. Major statistics of interest were food supply (calories), index of 
Table 1. Summary of key food indices (1960-2009).

\begin{tabular}{|c|c|c|c|c|}
\hline & Mean & Std & Min & Max \\
\hline \hline Food variability (\%) & 15.47 & 6.24 & 76.53 & 29.19 \\
\hline Food self sufficiency (calories) (\%) & 94.38 & 4.93 & 10.9 & 27.8 \\
\hline Fat supply (g/capita/day) & 16.64 & 3.69 & 16.98 & 2266 \\
\hline Food supply (kcal/capita/day) & 2028.95 & 183.94 & 38.7 & 57.1 \\
\hline Protein supply (g/capita/day) & 49.12 & 5.39 & $\$ 842,235$ & $\$ 39,887,040.77$ \\
\hline Food aid (US\$) & $\$ 14,653,397.60$ & $\$ 10,849,575.80$ & & \\
\hline
\end{tabular}

Source: FAO (2012)

variability of food production, food supply quantity (kcal/capita/day), fat supply quantity (g/capita/day), protein supply quantity (g/capita/day), GDP per capita, inflation rate (as an indicator of food prices) and bmi $[18,19]$. Most of the data is available from 1961 to 2009.

\subsection{Data Analysis}

Exploratory data analysis methods were used to analyze the various data sets mentioned in the section 3.2. Line and bar graphs were used to establish trends of variables over time while measures of central tendency helped to draw meaning from the dataset. The Statistical Analysis System (SAS) version 9.3 and the Statistical Package for Social Sciences (SPSS) were used to create graphs for different variables. The relationship between average bmi and predictor variables including inflation (a proxy for food prices), GDP per capita (a proxy for household wealth), food self sufficiency, fat supply quantity (g/capita/day), and food aid was evaluated using a double log multiple regression model shown below:

$$
\text { LnavBMI }=\ln \beta_{0}+\ln \text { inf }+\ln f s s+\ln \text { GDPcap }+
$$

$\ln$ fats $+\ln$ faid $+\varepsilon$

Where: Lnavbmi is average bmi, Lninf is the annual inflation rate, Lnfss is food self sufficiency, Lnfats is fat supply quantity (g/capita/day) and Lnfaid is food aid per year.

Food aid was expressed using 2011 constant dollar values. Since the dependent and independent variables were in logarithmic form, partial regression coefficients were interpreted as elasticity. Four assumptions of the multiple regression model were tested and these are the normality assumption, heteroscedasticity, autocorrelation and multicollinearity. The Shapiro-Wilks (SW) test was used to determine if the error term is normally distributed since this influences further hypothesis testing [20]. Furthermore, the SW test is normally recommended for small sample sizes of less than 50. Multicollinearity diagnostics were conducted using the variance inflation factor (VIF) with a threshold VIF value of less than 10 posing no computational problems for the regression model. In testing for the presence of heteroscedasticity, the Goldfeld-Quandt test was used while heteroscedastic consistent standard errors were used to correct the problem in the models. Autocorrelation was detected using Durbin-Watson test statistic and corrected using the "proc autoreg" function in SAS program. We present the results of this sub-section sequentially beginning with the preliminary double log model and subsequent models tested and corrected for Gauss-Markov conditions.

\section{RESULTS AND DISCUSSIONS}

\subsection{Key Food Production and Macroeconomic Variables in Rwanda}

Previous research on obesity has focused on the relationship between human diet and food supply [18]. Moreover, there is a positive link between poverty, low income, low education, poor food choices and obesity. It has been shown that large portion sizes, protein, calorie and fat supply all increase the chances of being obese [21]. Table 1 provides a summary of the main food production indices for Rwanda for the period 1960 to 2009.

Food self sufficiency indicates extent to which local agricultural production meets domestic food needs [19]. The index includes groups of commodities of similar nutritional values. In this case, we considered food self sufficiency in terms of calories. The main sources of calories in Rwanda include Irish potatoes, maize, cassava and sweet potatoes [22]. The food self sufficiency score for Rwanda between 1960 and 2009 is $94.38 \%$, and implies that approximately $94 \%$ of all food needs for the country comes from domestic supplies (Fig. 2). Many countries in Africa rely on imports to meet their food needs and currently the index for Africa is about 78\% [19]. The government crafted the Strategic Plan for the Transformation of Agriculture (I and II), whose main objective is to improve agricultural productivity in the country [22]. In addition, several strategies such the Crop Intensification Program, Land Use Consolidation, Land Husbandry, Water Harvesting and Hillside Irrigation (LWH) Project and Villagization program have resulted in the quantum changes and lower production risk in agriculture [14].

Food supply reveals the extent of national under nutrition in a given country [3]. Since 2005, Rwanda's food supply score has been above $2200 \mathrm{kcal} / \mathrm{capita} /$ day. In addition, in 


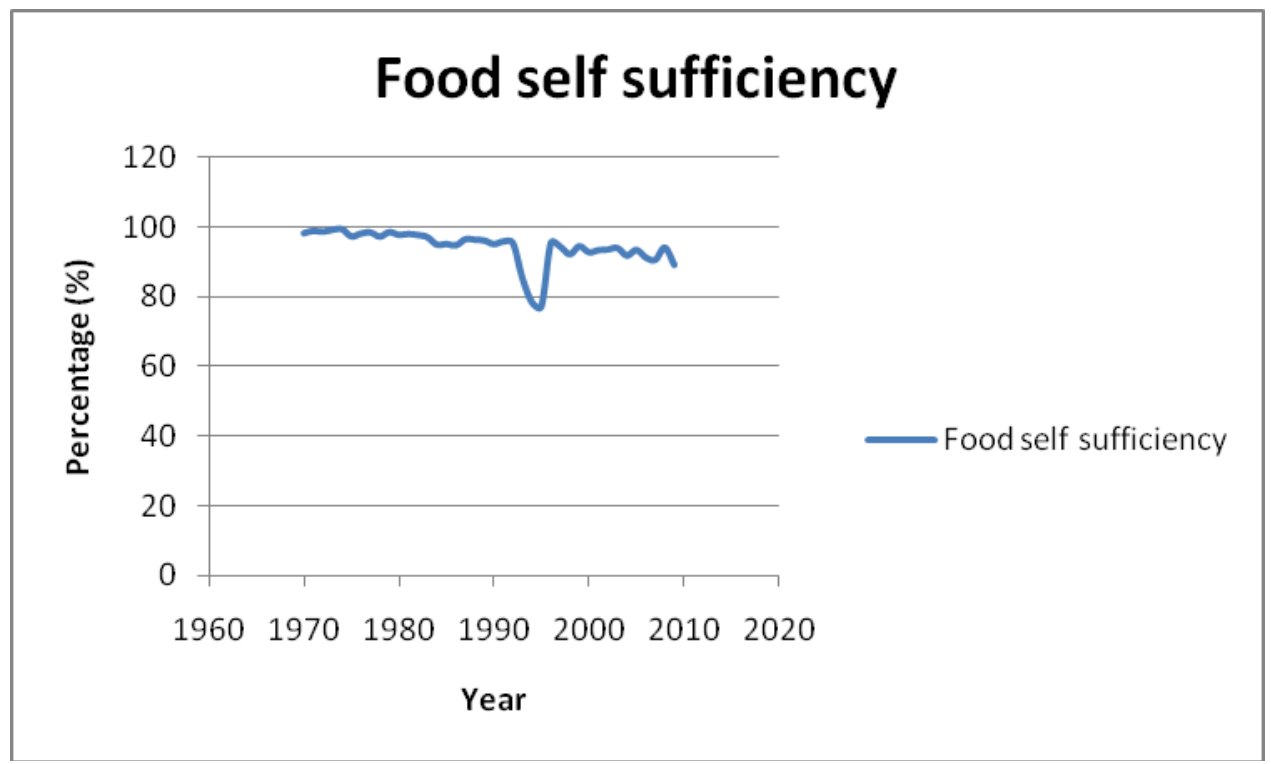

Fig. (2). Trends in food self sufficiency in Rwanda (1960-2009).

Source: FAO (2012)

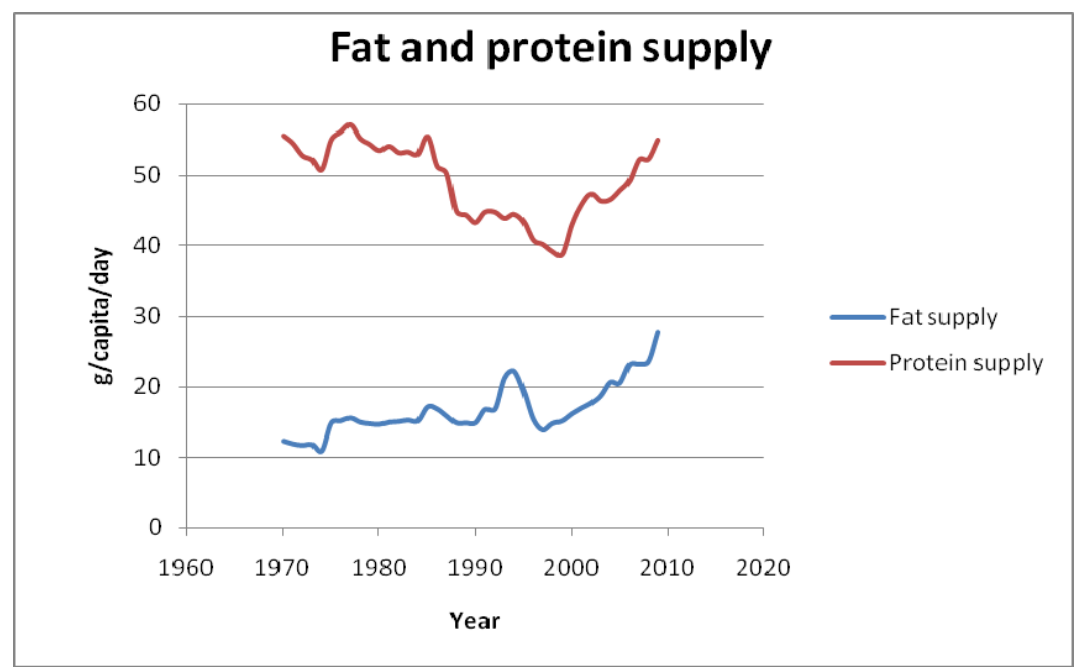

Fig. (3). Trends in fat and protein supply in Rwanda (1960-2009).

Source: FAO (2012)

Sub Saharan Africa, the food supply scores have hovered between 2058 and 2195 from 1961 to 1998 . Furthermore, the country's food supply score is higher when juxtaposed with its neighbors like the Democratic Republic of Congo whose score of about $1337.17 \mathrm{kcal} / \mathrm{capita} /$ day. Food variability score indicates the extent to which a country's food production system is vulnerable to both artificial and natural shocks such as rising food prices or climate change and higher scores are associated with higher levels of vulnerability [19]. Rwanda's food variability score in the last 50 years is $15.47 \%$ and it much lower than countries like Senegal with a score of $22.86 \%$ over the same period. Most developing countries, Rwanda included, have been relying on food aid to boost food available particularly for vulnerable populations. On average the country received about US\$14 million worth of food aid annually in the past 3 decades. The controversies that surround the provision have been the subject of much attention in literature. In this regard, several studies have shown that there are costs and benefits associated with aid that include decreases in the prices of local food products and misuse by public office but can be a source of essential nutrients for the needy [23, 24]. Rwanda, however, does not feature among the topmost countries receiving food aid that include Egypt, Ethiopia, Sudan and Mozambique. Fat supply indicator has been increasing over time but lower than the global average of $45 \mathrm{~g} / \mathrm{capita} / \mathrm{day}$ [19]. The increasing trends of protein and fat supply over time are shown in Fig. (3).

\subsection{Economic Indicators}

Economic theory posits that a change in relative prices and income will lead to greater food consumption [18, 25]. It is in this context that the current study considered relative 


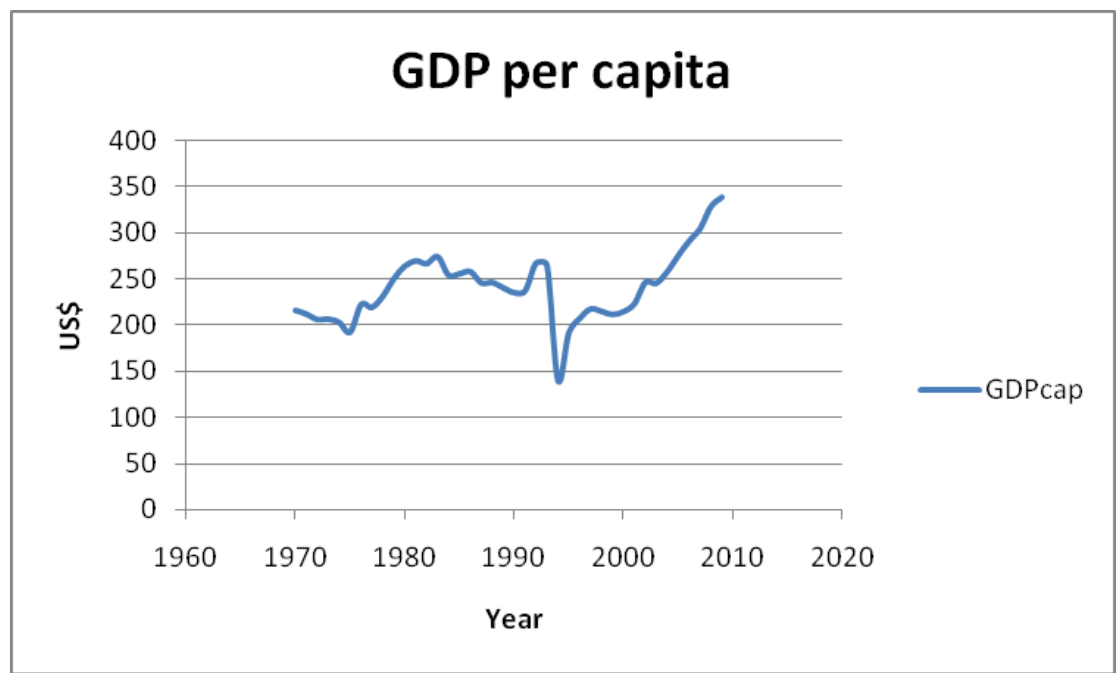

Fig. (4). Rwanda's GDP per capita in US\$.

Source: FAO (2012)

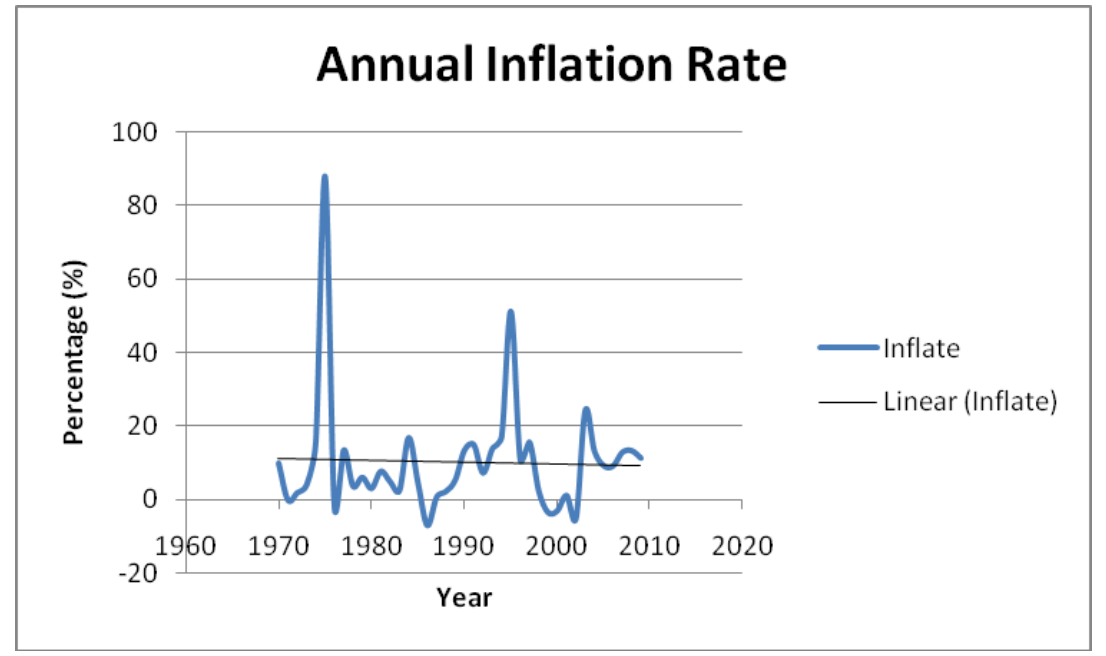

Fig. (5). Rwanda's inflation rate trend (1960-2009).

Source: FAO (2012)

food prices (inflation) and income (GDP per capita). Rwanda's economic performance, as reflected by the GDP per capita of US\$240.9, has improved by an average of $3.03 \%$ per annum over the last five decades. The economy has been growing by an average of $7 \%$ of the GDP per annum, the second highest after Mozambique [26]. This is higher than the average annual GDP growth per capita for Africa which was $0.9 \%$ between 1970 and 1990 and $2.1 \%$ between 1990 and 2010 [27]. Fig. (4) shows trends the in GDP per capita over the last 50 years. The effect of the genocide can be seen in both figures, with GDP per capita reaching its lowest point in 1994 and inflation was around $40 \%$. This pattern is also evident for the food supply indicator as well. Rwanda's inflation rate has been stable or slightly decreasing over time (Fig. 5) while the GDP per capita has been increasing since the turn of the millennium [28]. Since people respond to incentives, higher real disposable income will result in greater food consumption.
In the last decade, when GDP per capita was on the rise, food consumption (supply) also increased. Moreover, the provision of universal health care to about $92 \%$ of the population has resulted in an increase in life expectancy to 55 years from 38 years in 2001 [26].

\subsection{Body Mass Indices and Weight Gain in Rwanda}

(Fig. 6) shows the emerging trends of bmi for both male and female adults in Rwanda for the period 1980 to 2009. The average bmi for males and females over the 29 year period were 22.02 and 21.2 respectively. These results are at variance with Mokthar et al. [10] who found that more women weighed more than men in Tunisia and Morocco. These differences could be attributed to cultural differences and higher incomes among men in Rwanda. According to these results, it can be observed that the country did not suffer from an obesity or overweight problem (since they are 


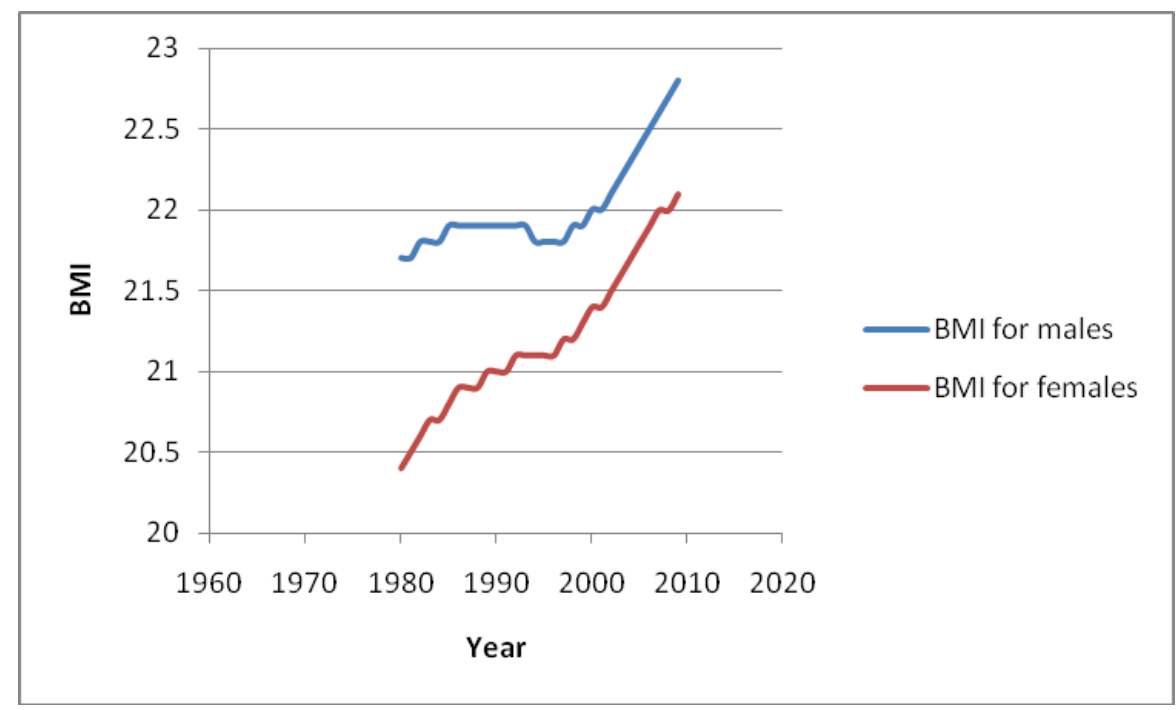

Fig. (6). BMI trends for adult males and females in Rwanda (1980-2009).

Source: WHO (2012)

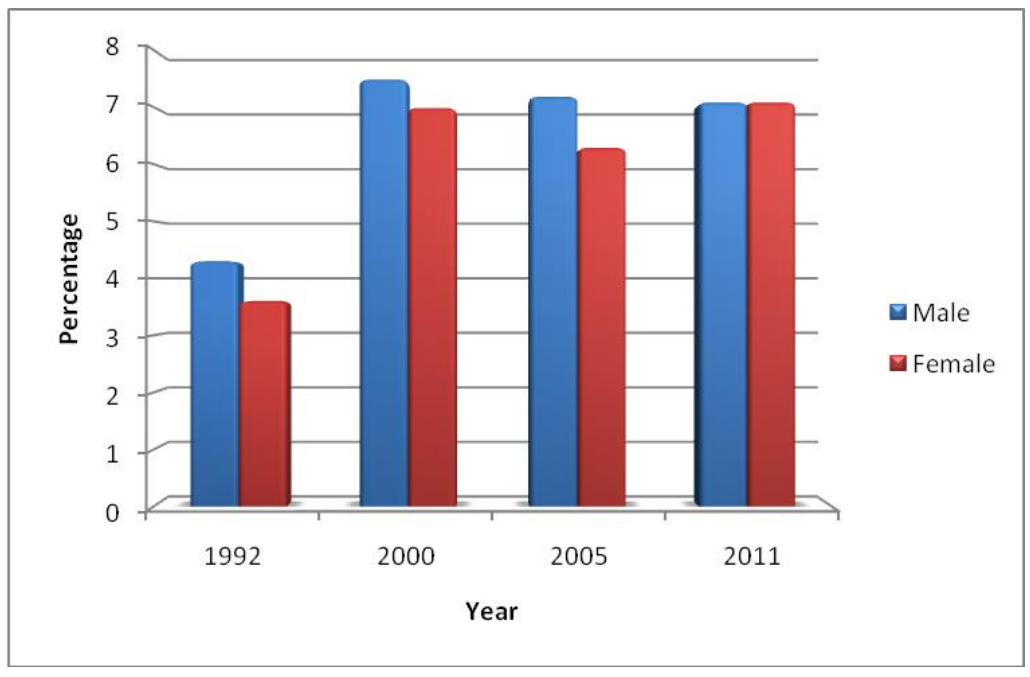

Fig. (7). Prevalence of obesity in children less than 5 years (\%).

Source: FAO (2012)

below the bmi=25 threshold). However, such a conclusion may be misleading because since 2007, the maximum recorded bmi for males in urban areas has been consistently over 25 [3]. This research also considered the prevalence of obesity statistics in children less than 5 years old. Fig. (7) shows the percentage of obese children since 1992.

In Sub Sahara, obesity in children has been increasing since the early 1990s [29]. It is further noted that childhood obesity stood at $4 \%$ in 1990 and rose to $8.5 \%$ in 2010 in the region but the average was $7 \%$. In Rwanda, childhood obesity increased from around 3\% in 1992 to slightly above $7 \%$ in 2010 (Fig. 7). Generally, a greater proportion of male children were obese when compared to their female counterparts. Childhood obesity was higher in Rwanda than the East African average of $7 \%$. Previous studies argue that genetic factors and environmental factors are important $[1,30]$. Obesity does co-exist with under-nutrition in the country. In $2000,20.3 \%$ of children less than 5 years were underweight while in 2010 approximately $11 \%$ were underweight [3].

\subsection{Relationship Between Average bmi and Predictor Variables}

The results of the preliminary double log multiple regression model are depicted in Table 2 . The R-square for the initial model was 0.84 indicating that $84 \%$ of the total variation in average bmi is attributed to the predictor 
Table 2. Results of the initial multiple regression model.

\begin{tabular}{|c|c|c|c|}
\hline Variable & Variable description & B & $<$-value \\
\hline \hline Intercept & Intercept & 2.17772 & 0.0001 \\
\hline Lninf & Annual inflation rate & 0.000695 & 0.7203 \\
\hline lnGDPcap & GDP per capita & -0.01025 & $0.0501^{*}$ \\
\hline Lnfss & Food self sufficiency & 0.12203 & $<0.0001^{* *}$ \\
\hline Lnfats & Fat supply (g/capita/day) & 0.09076 & $0.0053^{* *}$ \\
\hline lnfaid & Food aid in US\$ per year & 0.00834 & \\
\hline
\end{tabular}

**significance at $5 \%$ level

* significance at $10 \%$ level

Table 3. Multicollinearity diagnostics in the initial model.

\begin{tabular}{|c|c|c|}
\hline Variable & Variable Description & VIF \\
\hline \hline Intercept & Intercept & 1.41715 \\
\hline Lninf & Annual inflation rate & 3.46490 \\
\hline lnGDPcap & GDP per capita & 5.07900 \\
\hline Lnfss & Food self sufficiency & 4.01752 \\
\hline Lnfats & Fat supply (g/capita/day) & 1.16314 \\
\hline lnfaid & Food aid in US\$ per year & \\
\hline
\end{tabular}

Table 4. Multiple regression model corrected for autocorrelation.

\begin{tabular}{|c|c|c|c|}
\hline Variable & Variable Description & B \\
\hline \hline Intercept & Intercept & 2.4757 \\
\hline Lninf & Annual inflation rate & 0.000463 \\
\hline lnGDPcap & GDP per capita & 0.002652 \\
\hline Lnfss & Food self sufficiency & 0.0637 \\
\hline Lnfats & Fat supply (g/capita/day) & 0.8163 \\
\hline $\operatorname{lnfaid}$ & Food aid in US\$ per year & 0.071324 \\
\hline
\end{tabular}

$* *$ significance at $5 \%$ level

*significance at $10 \%$ level

variables included in the model. In addition, the model was significant with an F-value of 22.1 and a p-value less than $5 \%$. Two predictor variables fat supply and food aid had a positive and significant impact on bmi $(p<0.05)$ while food self sufficiency was significant at the $10 \%$ level $(\mathrm{p}<0.1)$. The initial model was subjected to tests of normality and multicollinearity. With regards to normality, the ShapiroWilks value was 0.97 and a p-value of 0.5557 resulting in the non-rejection of the normality assumption. Results of multicollinearity indicating VIF for each predictor variable are shown in Table 3.

Threshold VIF values of less than 10 reveal that multicollinearity is not a problem in the model [20]. Multicollinearity did not pose any structural challenges for the model since all VIF values were less than 10 . We then subjected the model to autocorrelation and heteroscedasticity. Durbin-Watson test value was 0.93 indicating positive autocorrelation $(\mathrm{p}<0.05)$. However, this problem was corrected using "proc autoreg" function in SAS (Table 4).

In the model corrected for positive autocorrelation, fat supply had a positive and significant effect on average bmi $(\mathrm{p}<0.05)$. Food aid, on the other hand, was statistically significant at $10 \%$ with the expected sign. Heteroscedasticity test results conducted using Goldfeld-Quant test are reflected in Table 5. Heteroscedasticity was present in four predictor variables inflation rate, food self sufficiency, fat supply and food aid while it was absent in GDP per capita. The variance 
Table 5. Heteroscedasticity diagnostics in the model.

\begin{tabular}{|c|c|c|c|c|c|}
\hline Variable & Variable Description & RSS2 & RSS1 & F-value & F(0.05, 14,14)=2.48 \\
\hline \hline Lninf & Annual inflation rate & 0.00277 & 0.00040955 & 6.76 & Present \\
\hline lnGDPcap & GDP per capita & 0.00002486 & 0.00235 & 0.01 & Not present \\
\hline Lnfss & Food self sufficiency & 0.00297 & 0.00008918 & 33.30 & Present \\
\hline Lnfats & Fat supply (g/capita/day) & 0.00195 & 0.00034722 & 5.61 & Present \\
\hline Lnfaid & Food aid in US\$ per year & 0.00357 & 0.00004535 & 78.72 & Present \\
\hline
\end{tabular}

Table 6. Corrected model with heteroscedastic robust standard errors.

\begin{tabular}{|c|c|c|c|c|}
\hline Variable & Variable Description & B & S.E & P-value \\
\hline \hline Intercept & Intercept & 2.17772 & 0.15161 & $<0.0001^{* *}$ \\
\hline Lninf & Annual inflation rate & 0.000695 & 0.00135 & 0.6120 \\
\hline lnGDPcap & GDP per capita & -0.01025 & 0.01270 & 0.4292 \\
\hline Lnfss & Food self sufficiency & 0.12203 & 0.04087 & $0.0073^{* *}$ \\
\hline Lnfats & Fat supply (g/capita/day) & 0.09076 & 0.01151 & $<0.0001 * *$ \\
\hline Lnfaid & Food aid in US\$ per year & 0.00834 & 0.00311 & $0.00144^{* *}$ \\
\hline
\end{tabular}

$* *$ significance at $5 \%$ level

of residuals was increasing for the four predictor variables inflation rate, food self sufficiency, fat supply and food aid. The corrected model using heteroscedastic robust standard errors is shown in Table 6.

The model corrected for heteroscedasticity had an adjusted R-square value of 0.8024 indicating that the predictor variables account for $80 \%$ of explained variation in average bmi. The model was also statistically significant at the $5 \%$ level $(\mathrm{p}<0.05)$. Three variables were significant namely food self sufficiency, fat supply and food aid $(\mathrm{p}<0.05)$. However, GDP per capita and annual inflation rate were not significant at the $5 \%$ level. In terms on interpretation, $1 \%$ change in food self sufficiency will lead to a $0.12 \%$ increase in average bmi, ceteris paribus. An increase in fat supply by $1 \%$ will increase average bmi by $0.09 \%$, holding other factors constant. Similarly, $1 \%$ change in food aid will increase average bmi by $0.008 \%$, ceteris paribus. Correlation coefficients for males and females were statistically significant at $5 \%$ and $10 \%$ respectively. Increases in food self sufficiency and fat supply can be attributed to a number of policy initiatives beneficial for the poor that the government of Rwanda has been implementing [15]. Examples of such strategies include the one cow per household whereby poor households receive one cow to ensure milk supply, manure and enhanced food security, and higher income opportunities [15, 31]. These results are consistent with relevant studies such as Mokhtar, et al. [10] who argued that fat intake had a positive effect on bmi in Morocco. A growing body of literature does indicate that participation in public food programs such as food stamps may exacerbate the weight gain in developed countries such as the U.S [32]. However, the same argument has rarely been put forward in the developing country context. Results in this study, however, point out that food aid might be contributing to weight gain problem in the country. Food aid has been shown to have deleterious effects on agriculture and its people [33]. Recent studies in Rwanda [34] observed that obesity was ubiquitous among affluent urban women, a result that is at variance with our findings. This could be attributed to the fact that secondary data was used and because it was aggregated, geographical variations were not reflected. Moreover, the sample size used was relatively small. Since this study used time series data, variations that exist due to socio-economic variables were not taken into account and cross-sectional studies may be conducted in this regard.

\section{CONCLUSION}

This study showed that there was no obesity in adults in Rwanda. However, average bmi has been increasing over time. Following previous studies, economic and food production variables such as food supply, food self sufficiency (calorie), inflation rate, GDP per capita were analyzed. The results showed that all food supply indices have been increasing over time. Inflation rate has been stable while income is rising. These factors may explain the upsurge in bmi in male and females. The results also revealed that there is a positive and significant relationship between average BMI, food self sufficiency, fat supply and food aid. Government has been promoting healthy living through consumer nutrition education and the promotion of 
sporting activities in schools and urban locales but there is a need to change attitudes. This will help in the transition from sedentary to active lifestyles. This study used aggregated data and there is a need to conduct further research at the household level to understand the socio-economic factors behind increases in bmi in the country.

\section{CONFLICT OF INTEREST}

The author confirms that this article content has no conflict of interest.

\section{ACKNOWLEDGEMENTS}

The author wishes to acknowledge Dr. Williamson, from Economics department, Mississippi State University, for providing data on food aid from various websites.

\section{REFERENCES}

[1] Hill JO, Wyatt HR, Reed GW, Peters JC. Obesity and the environment: Where do we go from here. Science 2003; 299(5608): 853-5.

[2] Moreno LA, Rodríguez G. Dietary risk factors for development of childhood obesity. Curr Opin Clin Nutr Metab Care 2007; 10(3): 336-41.

[3] WHO. Global and regional food consumption patterns and trends. 2012. Available from: http://www.who.int/nutrition/topics/3_foodconsumption/en/index.html [Accessed on 3/14/2013].

[4] Kelly T, Yang W, Chen CS, Reynolds K, He J. Global burden of obesity in 2005 and projections to 2030. Int J Obes (Lond) 2008; 32(9): 1431-7.

[5] Torabi MR, Lindeman AK, Dawkins E. Confronting the pandemic of obesity: A $21^{\text {st }}$ century public health crisis. In: Wright S, Ed. The $53^{\text {rd }}$ ICHPER.SD Anniversary World Congress; 2011 Dec 19-22; Cairo, Egypt: Fairmont Nile City Hotel 2011; pp. 7-24.

[6] Bray GA. Medical consequences of obesity. J Clin Endocrinol Metab 2004; 89(6): 2583-9.

[7] De Onis M, Blössner M. Prevalence and trends of overweight among preschool children in developing countries. Am J Clin Nutr 2000; 72(4): 1032-9.

[8] Ziraba AK, Fotso JC, Ochako R. Overweight and obesity in urban Africa: A problem of the rich or the poor? BMC Public Health 2009; 9(1): 465 .

[9] Caballero B. A nutrition paradox-underweight and obesity in developing countries. N Engl J Med 2005; 352(15): 1514-6.

[10] Mokhtar N, Elati J, Chabir R, et al. Diet culture and obesity in northern Africa. J Nutr 2001; 133(3): 887S-892S.

[11] Puoane T, Steyn K, Bradshaw D, et al. Obesity in South Africa: The South African demographic and health survey. Obes Res 2012; 10(10): 1038-48.

[12] National Institute of Statistics of Rwanda (NISR). Indicator Reports 2012. Kigali: Rwanda. Available from: http://www.statistics.gov.rw
[13] Ansoms A, Rostagno D. Rwanda's vision 2020 halfway through: What the eye does not see. Rev Afr Polit Econ 2012; 133: 427-50.

[14] Government of Rwanda. From Genocide to socio-economic development, country publications 2012. Kigali: Republic of Rwanda.

[15] Government of Rwanda. Vision 2020 policy, country publications. 2011. Kigali: Republic of Rwanda.

[16] Prentice AM. The emerging epidemic of obesity in developing countries. Int J Epidemiol 2006; 35(1): 93-9.

[17] Mazimpaka C, Abdi K. Obesity in our community 2012. Presentation at the National University of Rwanda, Department of General medicine, Rwanda 2012.

[18] Drewnowski A, Darmon N. The economics of obesity: Dietary energy density and energy cost. Am J Clin Nutr 2005; 82(1): 265S$73 \mathrm{~S}$.

[19] FAO. Global and regional food consumption patterns and trends 2012. Available from: http://www.fao.org/publications/sofi/foodsecurity-indicators [Accessed on 3/13/2013].

[20] Gujarati DN, Porter DC, Eds. Basic Econometrics. $5^{\text {th }}$ ed. Irwin: McGraw-Hill 1999.

[21] Young LR, Nestle M. The contribution of expanding portion sizes to the US obesity epidemic. J Inf 2002; 92(2): 246-9.

[22] Agriculture sector investment plan. Kigali: Republic of Rwanda MINAGRI 2009; p. 40.

[23] Uvin P. Aiding Violence: The development enterprise in Rwanda. West Hartford, CT: Kumarian Press 1998.

[24] Nunn N, Qian N. The determinants of food aid provisions to Africa and the developing world. (No. w16610). National Bureau of Economic Research. Working paper series, No w16610, Cambridge, Mass, National Bureau of Economic Research c2010.

[25] Powell DM, Reedy SE, Sessions DR, Fitzgerald BP. Effect of short-term exercise training on insulin sensitivity in obese and lean mares. Equine Vet J 2010; 34: 81-4.

[26] African development indicators. ADI. 2007. Available from: http://web.worldbank.org [Accessed January 2013].

[27] International Financial Statistics. UN data 2012. Available from: http://data.un.org/DataMartInfo.aspx on 10/26/12 [Accessed November 11, 2012].

[28] World Bank Report. Rwanda economic update. World BankDiscussion Papers 2011. Available from: http://www.worldbank.org/en/country/rwanda/ [Accessed on 15 January 2013].

[29] The obesity prevention source. Harvard School of Public Health 2010. Available from: http://www.hsph.harvard.edu/obesity [Accessed on 3/13/2013].

[30] Kopelman PG. Obesity as a medical problem. Nature 2000; 404(6778): 635-43.

[31] Issakson A. Manipulating the rural landscape: Villagisation and Income Generation in Rwanda. J Afr Econ 2013; 22(3): 394-436.

[32] Gibson D. Food stamp program participation is positively related to obesity in low income women. J Nutr 2003; 133(7): 2225-31.

[33] Moyo D, Ed. Dead aid: Why aid is not working and how there is a better way for Africa. USA: Macmillan Publishers 2009.

[34] Comprehensive africa agriculture development programme. East and central africa regional CAADP nutrition program development workshop. Nutrition country paper, February 2013, National Agricultural and Food Security Investment Plan. Dar-es-Salaam: Tanzania; 25 February-1 ${ }^{\text {st }}$ March 2013.

(C) Edward Mutandwa; Licensee Bentham Open.

This is an open access article licensed under the terms of the Creative Commons Attribution Non-Commercial License (http://creativecommons.org/licenses/by-nc/3.0/) which permits unrestricted, non-commercial use, distribution and reproduction in any medium, provided the work is properly cited. 